\title{
Efficacy and Deployment of Transgenic Plants for STEMbORER MANAGEMENT
}

\author{
David Bergvinson, Martha Willcox and David Hoisington \\ International Center of Maize and Wheat Improvement (CIMMYT), Lisboa 06600, Mexico D.F., \\ Mexico
}

(Accepted 8 October 1997)

\begin{abstract}
Transgenic plants expressing Bacillus thuringiensis $\delta$-endotoxins are now being used commercially in several crop species. These toxins have demonstrated good control of temperate (Ostrinia nubilalis) and tropical (Diatraea grandiosella and D. saccharalis) stemborers in maize. Resistance to $B$. thuringiensis toxins has been reported in over 11 species in both field and laboratory studies, demonstrating the need for resistance management strategies to prolong the efficacy of this valuable pest management tool within an integrated control programme. Resistance involves reduced binding of toxins to midgut epithelial cells and is generally considered to be a recessive trait. Resistance management will require the use of spatial and temporal refugia which may require unique schemes for each pest complex. Information is presented on the mode of action of cry toxins, resistance mechanisms, interaction of transgenic plants and biocontrol agents, and management/deployment strategies for transgenic maize in tropical ecologies.
\end{abstract}

Key Words: Diatraea grandiosella, Diatraea saccharalis, Spodoptera fugiperda, transgenic plants, Bacillus thuringiensis, $\delta$-endotoxin, tritrophic interactions, management, refugia

Résumé-Les plantes transgéniques qui expriment les $\delta$-endotoxines de Bacillus thuringiensis sont maintenant en train d'être utilisées commercialement dans plusieurs espèces de cultures. Ces toxines se sont révélées de bons agents de lutte contre les foreurs des tiges du maïs des zones tempérées (Ostrinia nubilalis) et des zones tropicales (Diatrea grandiosella et D. saccharalis). Une résistance aux toxines de $B$. thuringiensis a été rapportée chez plus de 11 espèces à partir des études de terrain et de laboratoire, démontrant le besoin des stratégies de contrôle de la résistance pour prolonger l'efficacité de cet outil de valeur dans le contrôle des ravageurs au sein d'un programme de lutte intégrée. La résistance implique la réduction de l'attachement des toxines sur les cellules épithéliales de l'estomac moyen et elle est généralement considérée comme un caractère récessif. Le contrôle de la résistance va nécessiter l'utilisation des refuges spatiaux et temporaires qui pourraient exiger des schémas uniques pour chaque complexe de ravageurs. Une information est fournie en ce qui concerne le mode d'action des cry toxines, les méchanismes de résistance, l'interaction entre plantes transgéniques et agents de lutte biologiqueainsi que des stratégies du contrôle/ déploiementpour lemaïs transgénique.

Mots Clés: Diatrea grandiosella, Diatrea saccharalis, Spodoptera fugiperda, plantes transgéniques, Bacillus thuringiensis, $\delta$-endotoxine, interactions tritrophiques, contrôle, refuges

\section{INTRODUCTION}

I ntegrated pest management has historically placed a great emphasis on the development of host plant resistance. The development of conventional host plant resistance often involved Corresponding author: DB. quantitative traits at several loci, making the resistance durable but difficult to achieve. With the advent of transformation techniques, genes which confer resistance to pest organisms have been inserted into crop plants including maize, rice, soybean, potato, tobacco and cotton (USDA, 1995; Bennett, 1994). 
Among the biological pesticides, bacteria have been the most successful group of organisms identified for insect control on commercial crops. The best examples of bacterial insecticides come from two soil bacteria, Bacillus thuringiensis and $B$. sphaericus (Gill et al., 1992; Charles et al., 1996). Insecticidal crystal proteins, called $\delta$-endotoxins, produced by these bacteria are highly toxic to certain pests, yet cause little or no harm to humans, most beneficial insects, and other non-target organisms (Croft, 1990). After being activated by midgut proteases, $B$. thuringiensis toxins bind to epithelial brush border membrane vesicles (BBMV), creating pores that result in cell lyses (Gill et al., 1992). Incorporation of genes encoding $\delta$-endotoxins into maize has provided high levels of resistance and tremendous excitement in crop protection. However, concerns over environmental hazards such as gene flow (Serratos et al., 1997) and widespread resistance in pest populations has restricted the deployment of toxin-producing plants.

Transgenic plants containing insecticidal proteins are set to feature prominently in agricultural systems in both developed and developing countries around the world. Entomologists, breeders, molecular biologists and population ecologists need to determine how to best deliver this technology to provide good pest control while at the same time reducing environmental hazards (including gene flow) and retarding the development of resistance in pest populations. To achieve these objects we need to have a greater understanding of the pest biology, behaviour and response to insecticidal proteins; the temporal and spatial expression of toxins in transgenic plants; the dynamics of differentrefugia strategies in resistance management; impact of toxin-producing plants on biological controls; and how to deliver this package to resource-poor farmers.

\section{Nomenclature, Structure aNd Mode of Action of $\delta$-ENDOTOXINS}

Bacillus thuringiensis is a gram-positive bacterium which produces a proteinaceous crystalline inclusion during sporulation. Several subspecies of $B$. thuringiensis produce these crystals which have insecticidal properties against lepidopteran, dipteran and coleopteran species. Because of the crystalline nature of these toxic proteins, the term 'cry' is used in gene and protein nomenclature. The current classification scheme was introduced by Höfte and Whiteley (1989). Toxin genes were then classified into four types based on insect specificity and sequence homology: Type-I genes encode proteins of $130 \mathrm{kDa}$ and are usually specific for lepidopteran larvae. Type-II genes encode 70 $\mathrm{kDa}$ proteins that are specific to both lepidopteran and dipteran larvae. Type-III genes encode for 70 $\mathrm{kDa}$ proteins that are specific to coleopteran larvae. Type-IV genes are specific to dipteran larvae. The nomenclature system has since been extended to include Type-V genes which are specific to both lepidopteran and coleopteran larvae (Tailor et al., 1992).

These crystalline inclusions are solubilised in the midgut at high $\mathrm{pH}$, releasing proteins called $\delta$ endotoxins. Delta-endotoxins are protoxins of approximately $130 \mathrm{kDa}$, except for CryII and III protoxins which are 70-75 kDa (Gill et al., 1992). Protoxins are activated by midgut proteases to yield 60 to $75 \mathrm{kDa}$ proteinase-resistant toxin fragments. The toxin portion is derived from the $\mathrm{N}$-terminal half of the protoxin. The C-terminal sequenceisinvolved in the formation of parasporal inclusions and is mostly hydrolysed into small peptides (Choma et al., 1990).

The region within the $\mathrm{N}$-terminal toxic domain (aminoacids 1-279) iscomposed of $\alpha$-helices which are considered important in penetrating the peritrophic membrane. At least six major $\alpha$-helices can be identified in most cry toxins. Based on the crystal structure of Cry IIIA, other cry proteins may adopt the same protein folding scheme with a central hydrophobic helix (helix 5) surrounded by sixamphipathichelices (Li etal., 1991).Reducing the hydrophobicity of these regions can reduce toxicity (Wu and Aronson, 1990). The C-terminal region (amino acids 461-695) and the highly variable region (amino acids 280-460) are considered importantintoxinspecificity by coding for open $\beta$-sheets that bind to glycoprotein receptors in the midgut. Using ${ }^{125}$ I-labelled toxins, brush border membrane vesicles (BBMV) were identified as the primary binding site for several insect species (Lee et al., 1992). BBMV studies show a positive correlation between toxin activity and ability to bind to BBMV (Gill et al., 1992). Furthermore, toxicity appears to be correlated with receptor number rather than receptor affinity (van Rie et al., 1989).

The toxicity of $B$. thuringiensis toxins lies in the organisation of the $\alpha$-helices derived from domain 
I. After binding to the midgut epithelial cells, the $\alpha$-helices can penetrate the apical membrane to form an ion channel (Knowles and Dow, 1993). Studiesusing CryIC toxin havedemonstrated these pores to possess both selective (only $\mathrm{K}^{+}$passes through) and non-selective ( $\mathrm{Na}^{+}$and anions pass) properties depending on $\mathrm{pH}$ (Schwartz etal., 1993). Since the lepidopteran insect midgut is alkaline, the pores most probably permit $\mathrm{K}^{+}$leakage. Formation of this cation-selective channel destroys membrane potentials (English and Slatin, 1992), resulting in midgut necrosis, degeneration of the peritrophic membrane and epithelium, and ultimately bacterial septicemia which occurs after larval death due to toxins (Salama and Sharaby, 1985; Sneh and Schuster, 1981).

\section{Development of Transgenic Plants containing Cry Genes}

Plant transformation was first achieved less than 15 years ago with the Agrobacterium-mediated introduction of kanamycin resistance into tobacco (Bevan et al., 1983). Since then, transformation technology has developed rapidly with particular emphasis being placed on cereals. The basic requirements for plant transformation are: (1) a target genome; (2) a vector to carry the gene(s) of interest; (3) modification of foreign DNA (i.e. bacterial origin) to increase expression in plant tissue; (4) methodology to deliver plasmid DNA into plant cells; (5) selection methodology to identify transformed cells; and (6) tissue culture methodology to recover viable plants from transformed cells. For maize, the nuclear genome has been the target for $B$. thuringiensis genes to provide heritable resistance to insects.

Recently, a large selection of vectors have been developed from bacterial plasmids. These vectors contain antibiotic resistance as selectable markers, a replication gene and a multiple cloning site (MCS) with several restriction sites for DNA insertion. Foreign DNA can be inserted into the vector using restriction enzymes that recognise a specific DNA sequence. Insertion of foreign DNA interrupts gene expression of an identifiable protein product to indicate DNA incorporation.

Construction of a DNA sequence for incorporation into vectors consists of several components. The $B$. thuringiensis gene must first be converted from AT-rich (typical of bacteria) to CG-rich (typical of higher plants) in order increase toxin expression. Most changes are made to the third codon, thereby minimising changes in the amino acid sequence but increasing expression of the $B$. thuringiensis toxin by 10 - to 100 -fold over native gene expression (Perlak et al., 1991). For expression of $B$. thuringiensis genesinhigher plants, a recognisable promoter and termination sequence must bracket the toxin gene. Popular constitutive promoters include the cauliflower mosaic virus (CaMV), 35S promoter and the ubiquitin promoter. Tissue-specific promoters used in maize include the PEP carboxylase promoter (green tissue) and a maize pollen-specific promoter (Koziel et al., 1993). Selectable markers, such as the bar gene which confers resistance to the herbicide phosphinothricin (PPT), are incorporated to facilitate the identification of transgenic plants. The size of successful vectors ranges from $5000 \mathrm{bp}$ to $11000 \mathrm{bp}$ depending on the promoters and $B$. thuringiensis genes incorporated into the vector (Koziel et al., 1993). Delivery of vectors into the nucleus of cereals has been achieved by using Agrobacterium-mediated transformation and the biolistic method (Raineri et al., 1990; Koziel et al., 1993).

\section{Effectiveness of Transgenic Maize in Controlling Cereal Stemborers}

The emergence of insect populations resistant to conventional insecticides and concern over pesticide loading in the environmenthas resulted in increased use of $B$. thuringiensis toxins for insect control. Commercial B. thuringiensis formulations contain a mixture of toxins. For example, Dipel $2 X$ (Abbot Laboratories, North Chicago, IL) is derived from $B$. thuringiensis subsp. kurstaki and contains CryIA(a), CryIA(b), CryIA(c), CryIIA and CryIIB. Similarly, XenTari(Abbot Laboratories) is derived from subsp. aizawai and contains CryIA(a), CryIA(b), CryIC, CryID and Cry IIB(Shelton et al., 1993) In contrast to the commercial formulations of $B$. thuringiensis, transgenic plants usually contain only one or two toxins which are highly effective against a target species (Armstrong et al., 1995; Koziel et al., 1993).

Published field trials of transgenic maize containing cryI-type genes developed by the private sector have demonstrated unequivocally the effectiveness of this control method against the European corn borer, Ostrinia nubilalis. In 1993, Monstanto Co. (700 Chesterfield Parkway North, St. Louis, MO 63198) evaluated transgenic maize 
by infesting plants three times with ca. 50 insects per application at the mid-whorl stage and again with 300 larvae applied at anthesis to simulate second-generation brood (Armstrong et al., 1995). Leaf-feeding damage was restricted to pin- and shot-holes while the second generation infestation generated 0.2 to 1 tunnel per plant compared to 9 tunnels per plant in untransformed plants (Armstrong et al., 1995). Field trials by CIBAGEIGY (Research Triangle Park, NC 27709) were conducted under extremely high pest pressure, with 2400 European corn borer larvae per plant at the mid-whorl stage and 1200 larvae per plant at anthesis. Leaf-feeding damage in this trial rated as low as 1.6 while checks rated 7.2 (scale of 1-10) (Koziel et al., 1993). Tunnelling damage by the second-generation infestation resulted in $59 \mathrm{~cm}$ of tunnelling in susceptible checks while only $1.7 \mathrm{~cm}$ of tunnelling was recorded for a transgenichybrid heterozygous for the cryIA(b) gene.

The effectiveness of transgenic plants against tropical stemborers is now being tested in both the public and private sectors. In collaboration with the private sector, transgenic maize is being tested at the International Center of Maize and Wheat Improvement (CIMMYT). Trials using three lepidopteran pests reared at CIMMYT were conducted in biosafety greenhouses designed to prevent pollen escape. The first trial investigated the level of leaf-feeding resistance of an Acquired Transgenic Maize (ATM) line containing cryIA(b) in comparison with a susceptible CIMMYT line (Table 1). Although the untransformed line used to carry the cryIA(b) gene was slightly more resistantto thetwo stemborers than the susceptible check, a dramatic reduction was observed for the line and hybrid containing the cryIA(b) gene. The hybrid showed a slightly lower damage rating which was probably due to hybrid vigour. The cryIA(b) gene did not have an impact on the fall armyworm, Spodoptera frugiperda.

Additional trials were conducted to compare the resistance levels conferred by cryIA(b) and conventional host plant resistance (HPR) developed at CIMMYT. Infestations with the southwestern corn borer, Diatraea grandiosella, demonstrated the superior level of resistance in transgenic maize (Table 2). Considerably lower leaf feeding damage ratings in the transgenic hybrid resulted in no larvae being collected from 30 infested plants. Larvae collected 25 days after infestation were smaller and fewer from the resistant hybrid CML139xCML67 than those on the susceptible hybrid. The effectiveness of the transgenic hybrid was less pronounced against the sugarcane borer, Diatraea saccharalis, with the level of resistance being comparable in both the cryIA(b) and hybrid with conventional resistance (Table 2). Low temperatures during the trial adversely affected $D$. saccharalis development. The final trial compared the levels of resistance against S. frugiperda (Table 2). Hybrid CML139xCML67 showed the best level of resistance, especially when comparing the mean larval weight which was an order of magnitude lower in larvae feeding on this hybrid. These studies show the effectiveness against two tropical stemborers of a $B$. thuringiensis toxin, CryIA(b), developed for a temperate stemborer, Ostrinia nubilalis.

Future work will focus on the identification of $B$. thuringiensis toxins that could be more affective against tropical cereal stemborers. Screening conducted at CIMMYT has identified CryIA(b) and CryIA(c) to be effective against $D$. grandiosella. Due to the binding specificity of $B$. thuringiensis toxins, each stemborer species of economic importance should be screened against a standard library of $B$. thuringiensis toxins to determine which constructs should be used within a region. Initial screening tests will have to be validated by testing the performance of transgeniclines against various stemborers of economic importance. Bioassays should also be conducted against predators and parasitoids to ensure the compatibility of cry genes and biological control strategies. The role of conventional resistance in transgenesis should

Table 1. Evaluation of maize lines and hybrids against Diatraea grandiosella, $D$. saccharalis and Spodoptera frugiperda

\begin{tabular}{lccc}
\hline Material & D. grandiosella & D. saccharalis $^{1}$ & S. $^{\text {frugiperda }}{ }^{1}$ \\
\hline CML216 (Susceptible check) & 10.0 & 10.0 & 9.5 \\
Line without cryIA(b) & 9.5 & 9.5 & 10.0 \\
Line with cryIA(b) ATM & 2.6 & 2.5 & 8.7 \\
Hybrid with cryIA(b) ATM & 2.4 & 2.4 & 8.0 \\
\hline
\end{tabular}

1Plants were infested with 50 larvae at the 6-leaf stage. Ratings were based on a 110 scale with 10 being dead (Mihm, 1989).

${ }^{2} \mathrm{ATM}=$ Acquired Transgenic Maize. 
Table2. Leaf feeding damage and larval performance on maize hybrids against Diatraea grandiosella, D. saccharalis, Spodoptera frugiperda ${ }^{+}$

\begin{tabular}{|c|c|c|c|c|c|}
\hline & Material & $\begin{array}{l}\text { Leaf damage } \\
\text { rating }\end{array}$ & $\begin{array}{l}\text { Number } \\
\text { of larvae }\end{array}$ & $\begin{array}{l}\text { Total larval } \\
\text { weight (mg) }\end{array}$ & $\begin{array}{c}\text { Average larval } \\
\text { weight (mg) }\end{array}$ \\
\hline D. grandiosella & $\begin{array}{l}\text { CML } 216 \times \text { ATMcryIA(b) } \\
\text { CML } 139 \times \text { CML } 67 \\
\text { CML } 78 \times \text { CML } 216 \\
\text { Std Err. (SE) }\end{array}$ & $\begin{array}{l}2.5 \\
6.2 \\
7.7 \\
0.19\end{array}$ & $\begin{array}{c}0 \\
13 \\
27 \\
6.7\end{array}$ & $\begin{array}{r}0 \\
310 \\
3250 \\
700\end{array}$ & $\begin{array}{r}0 \\
27 \\
100 \\
15\end{array}$ \\
\hline D. saccharalis & $\begin{array}{l}\text { CML } 216 \times \text { ATMcryIA(b) } \\
\text { CML } 139 \times \text { CML } 67 \\
\text { CML } 78 \times \text { CML } 216 \\
\text { Std Err. (SE) }\end{array}$ & $\begin{array}{l}3.2 \\
3.8 \\
6.3 \\
0.33\end{array}$ & $\begin{array}{l}0.04 \\
0 \\
9.71 \\
1.2\end{array}$ & $\begin{array}{l}0 \\
0 \\
0.1 \\
0.144\end{array}$ & $\begin{array}{l}0 \\
0 \\
0.009 \\
0.031\end{array}$ \\
\hline S. frugiperda & $\begin{array}{l}\text { CML } 216 \times \text { ATMcryIA(b) } \\
\text { CML } 139 \times \text { CML } 67 \\
\text { CML } 78 \times \text { CML } 216 \\
\text { Std Err. (SE) }\end{array}$ & $\begin{array}{l}6.8 \\
5.3 \\
7.4 \\
0.24\end{array}$ & $\begin{array}{l}1.15 \\
0.8 \\
3.04 \\
1.45\end{array}$ & $\begin{array}{l}- \\
- \\
- \\
-\end{array}$ & $\begin{array}{l}0.14 \\
0.014 \\
0.22 \\
0.056\end{array}$ \\
\hline
\end{tabular}

+Plants were infested with $40 \mathrm{~S}$. frugiperda larvae and 45 Diatraea larvae at the 5-leaf and 6-leaf stage in plant development, respectively. Ratings were based on a 1-10 scale with 10 being dead (Mihm, 1989). Number of larvae is based on a 10 plant sample, 3 replicates.

also be examined as synergism between HPR and B. thuringiensis has been reported for Trichoplusia nicontrol(Gibsonetal., 1995) and such interactions could extend the effectiveness of transgenic plants containing cry genes for cereal stemborer control. Collaboration between International Agricultural Research Centres, National Agricultural Research Centres and the Private Sector is necessary to identify active $B$. thuringiensis toxins and other insecticidal polypeptides for stemborers of local importance, to assess their impact on insect ecosystems and to identify deployment strategies that delay resistance development in pest populations.

\section{CoMpatibILITY OF $\boldsymbol{B}$. THURINGIENSIS Toxins and Biological Control STRATEGIES}

Host plant resistance (HPR) and biological control are considered to be compatible components in an integrated pest management programme (Adkisson and Dyck, 1980).HPR reduces the need for insecticides which can have adverse effects on natural enemies. Conventional HPR can also slow the rate of increase of pest populations, thereby exposing pests to biological control agents for prolonged periods (Starks et al., 1972). However, some qualitative defense compounds such as nicotine can be antagonistic to biological controls (Barbosaetal.,1986). The introduction of transgenic plants brings a new system of HPR into play which could impact on tritrophic interactions.

Due to the recent release of transgenic plants for field testing, only a few studies have been conducted on the impact of transgenics on biological control agents. No studies have been published to date on the interaction between transformed cereals, stemborers and biological control agents. Field trials have been designed to assess the impact of transformed tobacco on parasitoids of Heliothis virescens (Johnson and Gould, 1992). This study consisted of four treatments: transgenic plants either exposed or excluded from natural enemies and toxin-free -plants either exposed to or excluded from natural enemies. Toxin-expressing plants reduced the number of surviving larvae to approximately half thatfound onnon-toxic plants. Percent parasitism was highly variable, but in one location percent parasitism by Campoletis sonorensis was significantly higher on toxin-producing plants. Two possible explanations for the observed biocontrol efficiency in toxin-producing plants are: (1) $H$. virescens development was $10-20 \%$ slower on toxin-producing plants, and (2) fewer larvae were available for parasitism on toxinproducing plants. Although the data supporting synergistic interactions was weak, there appeared to be no antagonistic interactions between toxinproducing plants and parasitoids. However, these transgenic plants caused only $80-90 \%$ mortality of $H$. virescens compared to $40-50 \%$ in non-toxic plants. Toxic plants which kill all larvae within 2 instars would probably impact parasite populations by not providing a sufficiently large host for parasite development. Likewise, laboratory studies of Leptinotarsa decemlineata and an active predator, Coleomegilla maculata, showed no adverse effect on predator performance when exposed to a $B$. thuringiensis-based insecticide (M- 
One, Mycogen, San Diego, CA) at the recommended dosage (Giroux et al., 1994). However, in choice studies, C. maculata showed a significant preference for control eggs of $L$. decemlineata than those treated with M-One at a rate tenfold higher than the manufacturer's recommended rate.

Based on these and other preliminary studies, $B$. thuringiensis-based transgenic maize should not adversely affect biological control agents of cereal stemborers. Studies will be required to characterise the impact of biological controls first at a laboratory level using artificial diets and then at the field level once transgenic plants are made available and biosafety regulations are in place. The use of models to gain further understanding of the interaction between transgenic plants and biological controls will also assist in minimising adverse effects and capitalising on any synergism between these two controlstrategies (Gould, 1994). Modelling will also be of benefit when determining the optimal design for refugia in resistance management and the role biocontrol agents play in delaying the establishment of resistant individuals.

\section{MANAgement of B. THURINGIENSIS- Based Transgenic Plants}

Diamondback moth, Plutella xyllostella, populations in many parts of the world have already developed resistance to $B$. thuringiensis formulations (Tabashnik, 1994). Laboratory screening for $B$. thuringiensis-toxin resistance has resulted in the development of tolerant populations in the following species: (Lepidoptera) Heliothis virescens, Spodoptera exigua, Spodoptera littoralis, Trichoplusia ni, Plutella xylostella, Anagasta kuehniella, Cadra cautella, Homoeosoma electellum, Plodia interpunctella, Choristoneura fumiferana; (Coleoptera) Chrysomela scripta, Leptinotarsa decemlineata; (Diptera) Aedes aegypti, Culex quinquefasciatus, Drosophila melanogaster, and Musca domestica (Tabashnick, 1994). This rather impressive list of resistant populations highlights the fact that resistance development in field populations is a very real concern for transgenic plants containing cry genes. With transgeniccereals now being produced in both private and public sectors, the formidable task ahead is to determine the best deployment strategy for transgenic plants that will lead to sustained protection against tropical insect pests.

Cry-toxin-resistant populations of cereal stemborers have not been reported in the literature but the deployment of transgenic maize in the United States will prompt the publication of such reports for the European corn borer, O. nubilalis. Based on earlier publications, Tabashnik (1994) concluded that initial gene frequencies for Cry toxin resistance were higher than $0.5 \%$. Estimates of resistant gene frequency may also be influenced by the nutritional status of eggs. Rossiter et al. (1990) has shown that the eggs of Lymantria dispar L. which are laid firsthave a $20-400$ percent increase in Cry toxin tolerance than later egg masses from the same cohort. Therefore, genetic studies should include all individuals from a defined population and not just a fraction which emerge at a given time.

Studies conducted in biosafety greenhouses at CIMMYT have determined the initial frequency and rate of resistance development in tropical stemborer populations to transgenic maize containing cryIA(b). Based on these results, resistance could develop rather quickly for $D$. saccharalis as a moderately high proportion of neonate larvae in the population could survive 8 days on transgenic maize (Table 3). However, D. grandiosella had a significantly ( $t$-test, $P<0.05$ ) lower frequency of surviving individuals. Surviving larvae were transferred to artificial diet and their progeny will be applied to the same

Table 3. Larval survivorship of two Mexican stemborer species after 8 days of feeding on transgenic maize containing a single copy of cryIA(b)

\begin{tabular}{|c|c|c|c|c|c|c|}
\hline \multirow[b]{2}{*}{$\begin{array}{l}\text { Stemborer } \\
\text { species }\end{array}$} & \multicolumn{3}{|c|}{ 6-leaf stage infestation } & \multicolumn{3}{|c|}{ 8-leaf stage infestation } \\
\hline & $\begin{array}{l}\text { Larvae } \\
\text { per } \\
\text { plant }\end{array}$ & $\begin{array}{c}\text { Number } \\
\text { surviving per } \\
\text { plant }(N \pm S E)^{*}\end{array}$ & $\begin{array}{l}\text { Survival } \\
\text { ratio* }^{*}\end{array}$ & $\begin{array}{c}\text { Larvae } \\
\text { per } \\
\text { plant }\end{array}$ & $\begin{array}{c}\text { Number } \\
\text { surviving per } \\
\text { plant }\end{array}$ & $\begin{array}{c}\text { Survival } \\
\text { ratio }^{+}\end{array}$ \\
\hline Diatraea saccharalis & 600 & $6.43 \pm 1.57 \mathrm{a} / \mathrm{a}$ & 0.011 & 250 & $27.12 \pm 9.18 \mathrm{a} / \mathrm{b}$ & 0.109 \\
\hline Diatraea grandiosella & 550 & $0.56 \pm 0.18 \mathrm{~b} / \mathrm{a}$ & 0.001 & 250 & $1.75 \pm 0.25 b / b$ & 0.007 \\
\hline
\end{tabular}

*Means within columns and rows (column/ row) with a different letter are significantly different $(P$ $<0.05, t$-test).

+Survivorship was determined on a population basis. 
transgenic hybrid for 8 days in order to culture resistant populations and determine the rate and magnitude of resistance development in these two Diatraea spp.

Avoidance may be one strategy that larvae can employ against transgenic plants. Choice studies using Heliothis virescens have shown susceptible larvae to avoid diet containing $B$. thuringiensis toxin (Gould and Anderson, 1991). An interesting observation from Table 3 is the significant and consistent difference in reduced survival of larvae placed on 6-leaf compared to 8-leaf plants. One possible reason for this could involve an avoidance strategy as younger plants (6 leaf) tend to have more exposed whorls with greater light penetration. The current cryIA(b) construct employs a PEP-carboxylase promoter which enables Cry-toxin expression in green tissue only so toxin levels may be greater in younger plants which have allleaf tissue exposed to light. The two borer species reared at CIMMYT tend to migrate into the whorl with little feeding until reaching the leaf tissue that has incomplete chlorophyll formation in the leaf. If the toxin is expressed at a sufficiently low level inside the whorl, larvae could survive the duration of the screening. Live larvae from both borer species were collected only from the immature leaf tissue within the whorl. Given the feeding preference for inner whorl tissue, behavioral avoidance of toxic tissues will likely be one component in stemborer resistance to transgenic maize.

Reduced binding affinity of Cry toxins onto the BBMV of the midgut epithelium has been identified as the resistance mechanism operating in Plutella interpunctella (van Rie et al., 1990) and $P$. xylostella (Ferré et al., 1991). Van Rie et al. (1990) demonstrated that a 50 -fold reduction in CryIA(b) binding was associated with $>100$-fold reduction in toxicity in the resistant versus susceptible populations of $P$. interpunctella. Midgut proteases were similar in both populations suggesting that altered proteolytic processing was not the mechanism of resistance (Johnson et al., 1990). Other resistance mechanisms are probably operating in some species as Gould et al. (1992) found no significant change in toxin binding to BBMV of a resistant population of $H$. virescens. Moreover, $H$. virescens selected on CryIA(c) showed $>500$-fold increasein resistance to CryIA(c) after 19 cycles butwasalso cross-resistantto CryIB, CryIC and CryIIA (Gould et al., 1995), implying a broader-based resistance mechanism. An additional resistance mechanism may also involve the complete degradation of Cry toxins by proteolytic enzymes, as has been reported for $S$. frugiperda (Keller et al., 1996). As workin resistance mechanisms continues, additional physiological, behavioral and biochemical mechanisms will likely be discovered. Resistance may include lower gut $\mathrm{pH}$ that would reduce crystal dissolution, altered protease enzymes that would reduce activation of protoxins or reduced sensitivity of epithelial cells to pore formation.

The inheritance of resistance traits appears to be mostly recessive and apparently due to one or a few major loci (Tabashnik, 1994). However, resistance in $H$. virescens (50-fold) was partially recessive and was thought to be inherited as an additive trait involving morethanonelocus (Gould et al., 1992), but a different strain (3000-fold resistance) demonstrated a single, recessive locus which conferred resistance and occurred at an initial frequency of $10^{-3}$ (Gould et al., 1995). Mapping of loci conferring resistance in pest populationswill be the nextstepingeneticstudies and the information obtained will provide further insight into resistance mechanisms as well asbeing used to monitor resistance development in pest populations.

Deployment of insecticidal plants should be couched within the philosophy of IPM. Such a strategy would not only consider gene construct and field design but would also consider alternate mortality mechanisms, means to reduce selection pressure on major mortality mechanisms, maintain susceptible individuals in the population and monitor pest populations for resistance to design more effective management strategies. This is especially true when considering food security in developing countries, as resistancebreak-through may leave resource-poor farmers in a vulnerable position unless other control strategies are developed as a backstop to insect-related yield losses. Those involved in the development and implementation of insecticidal plants have two major questions to address: (1) which cry genes will be used and how effective are they (expression level and toxicity) in controlling targeted pests and, (2) how will these plants be grown in the field to minimise resistance development? A list of the more popular tactics for deploying insecticidal plants is provided in Table 4. Gould (1986) has developed simulation models to compare the utility of different release strategies of two single gene factors: sequentially, cultivar mixture or a singlepyramided resistant cultivar. Thebest option depends on the inheritance, epistasis and initial 
Table 4. Tactics available for the deployment of insecticidal genes in crops

\begin{tabular}{|c|c|}
\hline Category & Tactics \\
\hline Gene strategies & $\begin{array}{l}\text { Single gene } \\
\text { Multiple genes (pyramid) } \\
\text { Chimeric genes }\end{array}$ \\
\hline Gene promoter & $\begin{array}{l}\text { Constitutive } \\
\text { Tissue-specific } \\
\text { Inducible (wound, phenology, } \\
\text { elicitor) }\end{array}$ \\
\hline Gene expression & $\begin{array}{l}\text { High dose } \\
\text { Low dose } \\
\text { Mixture (high/low) }\end{array}$ \\
\hline Field design & $\begin{array}{l}\text { Uniform single gene } \\
\text { Mixture of genes } \\
\text { Gene rotation } \\
\text { Mosaic planting (susceptible, } \\
\text { resistant cultivars) } \\
\text { Refugia (spatial, temporal) }\end{array}$ \\
\hline
\end{tabular}

Adapted from McGaughey and Whalon (1992), p. 1453.

frequency of resistant alleles in the pest population. If resistance alleles are recessive and epistasis is strong, making the two resistance factors redundant, pyramided deployment was predicted to be the most durable. What is clear from this and other models is the importance of refugia in resistance durability.

Refugia can be defined as a food resource in time or space that does not impose a selection pressure so as to maintain a susceptible population base to mate with resistant individuals. The optimal spatial or temporal scale of refugia will likely be unique for each insect-plant interaction. For refugia to be effective, no selection pressure should beapplied (i.e.insecticides) and individuals should be in suitable proximity to mate with survivors from insecticidal plants. Refugia can be placed within a given plant (tissue- or developmental-specific promoters), between plants (mixed seed) or between fields. In addition to maintaining resistance alleles at a low frequency, refugia also enhance the capacity of biological controls. Recentsimulations (Gould, 1994) indicate that natural enemies can slow the rate of pest adaptation to plants with high levels of HPR if these plants are grown near other plants that are susceptible to the pest insect. This is especially true if predation is inversely density-dependent and insecticidal plants are mixed with nontransgenic plants at a plot-to-plot spatial scale. One practical example of refugia is found in transgenic cotton farming in which the farmers (contract with the seed producer to) either plant
$20 \%$ of their land with conventional cotton and use non- $B$. thuringiensis insecticides to control Helicoverpa zea populations or plant $4 \%$ of their land with conventional cotton with no insecticide use. Using either method, sufficient insects survive to mate with individuals emerging from transgenic cotton to delay the appearance of homozygous resistant individuals.

Most models developed to date are simple, considering one crop, one pest and one biological control organism. In reality, cereal systems in tropical environments have a number of important pests which are often polyphagous with different biocontrol agents being active at different stages of pest and plant development. Given this complexity, constructs should be designed with these considerations in mind. Moreover, pests in tropical environments are capable of completing several life cycles per cropping season and tropical stemborers tend to be more aggressive than temperate species in their feeding behaviour. To address the complexity of transgenic management for cereal stemborers, there is a genuine need for more information on insect performance against different $B$. thuringiensis toxins and other insectactive polypeptides, species distribution within different regions as well as on a smaller scale between cultivated and wild hosts, and the impact of natural enemies on stemborer populations. As this basic information is obtained, prediction models can become more sophisticated in predicting the optimal deployment strategy for transgenic plants.

One possible product development strategy in maize is the production of targeted synthetics. By incorporating various constitutively expressed Cry toxins or other insect-active polypeptide genes into lines adapted for specific tropical environments, synthetics can quickly be formed which are effective against a pest complex and compatible with important biological control agents. For this to be effective, each tropical pest of maize and associated biological control agents must be properly characterised for their sensitivity to different constructs. Based on toxicity and line adaptation to the target environment, 6-10 lines expressing different toxins and specialty traits (tolerance to drought and/or low soil nitrogen, conventional HPR, disease resistance) would be recombined to form a homogeneous synthetic which would effectively 'pyramid' or 'stack' resistance genes into a maize synthetic. Once released to farmers, these synthetics could be maintained as narrow-based populations at the 
farm level by eliminating tassels of plants showing insect damage. This system would also lend itself to the incorporation of lines with conventional resistance to reduce the selection pressure on Cry toxins, thereby increasing the durability of resistant germplasm. Thenumber of cry-lines would depend on the expense of transformation and/or backcrossing to incorporate cry genes and the number of constructs available. Such a scheme could provide synthetics with good yield potential as well as stability from insect losses.

\section{Conclusion}

Incorporation of $B$. thuringiensis genes coding for insect toxins will have a tremendous global impact on cereal stemborer management in the next decade. Researchers in both the public and private sector as well as legislators need to actively pursue a management strategy that reflects the pest biology and interactions with the crop and associated biological controls to extend the lifetime of transgenic plants. Refugia will play a crucial role in resistance management and as such should be tailored to each pest complex and environment where transgenic plants are deployed. Bacillus thuringiensis toxins provide a unique source of insect control that delivers specificity, is environmentally sound, and can be effectively incorporated intoimportant crop species. Loosing such a control strategy will also have a tremendous global impact, especially for the resource-poor farmer who may not have alternate control strategies in place once resistant insect populations develop.

Acknowledgments-The authors wish to thank Dr H. Kumar for assistance evaluating trials. Financial assistance provided by the UNDP project Nos. GLO/90/003 and GLO/91/014 for the development of stress-resistant and transgenic maize, respectively. The opinions expressed in this paper are the responsibility of the authors.

\section{REFERENCES}

Adkisson P.L. and DyckV.A. (1980) Resistant varieties in pest management systems, pp. 233-253. In Breeding Plants Resistant to Insects (Edited by F. G. Maxwell and P. R. Jennings). Wiley, New York.

Armstrong C. L., Parker G. B., Pershing J. C., Brown S. M., Sanders P. R., Duncan D. R., Stone T., Dean D. A., DeBoer D. L., Hart J., Howe A. R., Morrish F.M., Pajeau M. E., Petersen W. L., Reich B. J., Rodriguez R., Santino C. G., Sato S. J., Schuler W., Sims S. R.,
Stehling S., Tarochione L.J. and Fromm M.E. (1995) Field evaluation of European corn borer control in progeny of 173 transgenic corn events expressing an insecticidal protein from Bacillus thuringiensis. Crop Sci. 35, 550-557.

Barbosa P., Saunders J. A., Kemper J., Trumbule R., Olechno J. and Martinat P. (1986) Plant allelochemicals and insect parasitoids: Effects of nicotine on Cotesia congregata (Say) (Hymenoptera: Braconidae) and Hyposoter annulipes (Cresson) (Hymenoptera: Ichneumonidae). J. Chem. Ecol. 12,1319-1328.

Bennett J. (1994) DNA-based techniques for control of rice insects and diseases: Transformation gene tagging and DNA fingerprinting, pp. 147-172. In Rice Pest Science and Management (Edited by P. S. Teng, K. L. Heong and K. Moody). International Rice Research Institute, Los Baños, Philippines.

Bevan M., Flavell R. N. and Chilton M. D. (1983) A chimeric antibiotic resistance gene as a selectable marker for plant cell transformation. Nature 304, 184-187.

Charles J. -F., Nielsen-LeRoux C. and Delécluse A. (1996) Bacillus sphaericus toxins: Molecular biology and mode of action. Annu. Rev. Entomol. 41, 451472.

Choma C. T., Surewicz W. K., Carey P. R., Pozsgay M. and Raynor T. (1990) Unusual proteolysis of the protoxin and toxin from Bacillus thuringiensis: Structural implications. Eur. J. Biochem. 189, 523527.

Croft B. A. (1990) Arthropod Biological Control Agentsand Pesticides. John Wiley and Sons, New York. 723 pp.

English L. and Slatin S. L. (1992) Mode of action of $\delta$ endotoxins from Bacillus thuringiensis: A comparison with other bacterial toxins. Insect Biochem. Molec. Biol. 22, 1-7.

FerréJ.S., Real M.D., van Rie J., Jansens S. and Peferoen M. (1991) Resistance to the Bacillus thuringiensis bioinsecticide in a field population of Plutella $x y$ lostella is due to a change in a midgut membrane receptor. Proc. Natl. Acad. Sci. USA 88, 5119-5123.

Gibson D. M., Gallo L. G., Krasnoff S. B. and Ketchum R. E. B. (1995) Increased efficiency of Bacillus thuringiensis subsp. kurstaki in combination with tannic acid. J. Econ. Entomol. 88, 270-277.

Gill S. S., Cowles E. A. and Pietrantonio F. V. (1992) The mode of action of Bacillus thuringiensis endotoxins. Annu. Rev. Entomol. 37, 615-636.

Giroux S., Cot J. C., Vincent C., Martel P. and Coderre D. (1994) Bacteriological insecticide M-one effects on predation efficiency and mortality of adult Coleomegilla maculata lengi (Coleoptera: Coccinellidae). J. Econ. Entomol. 87, 39-43.

Gould F. (1986) Simulation models for predicting durability of insect-resistant germplasm: A deterministic diploid, two-locus model. Environ. Entomol. 15, 1-10.

Gould F. (1994) Potential and problems with high dose strategies for pesticidal engineered crops. Biocontrol Science \& Technol. 4, 451-461. 
Gould F. and Anderson A. (1991) Effects of Bacillus thuringiensis and HD-73 delta-endotoxin on growth, behavior, and fitness of susceptible and toxinadapted strains of Heliothis virescens (Lepidoptera: Noctuidae). Environ. Entomol. 20, 30-38.

Gould F., Anderson A., Reynolds A., Bumgarner L. and Moar W. (1995) Selection and genetic analysis of Heliothis virescens (Lepidoptera: Noctuidae) strain with highlevels of resistance to Bacillus thuringiensis toxins. J. Econ. Entomol. 88, 1545-1559.

Gould F., Martinez-Ramirez A., Anderson A., Ferré J., Silva F. J. and Moar W. (1992) Broad-spectrum resistance to Bacillus thuringiensis toxins in Heliothis virescens. Proc. Natl. Acad. Sci. USA 89, 7986-7990.

Höfte H. and Whiteley H. R. (1989) Insecticidal crystal proteins of Bacillus thuringiensis. Microbiol. Rev. 53, 242-255.

Johnson D. E., Brookhart G. L., Kramer K. J., Barnett B. D. and McGaughey W. H. (1990) Resistance to Bacillus thuringiensis by the Indian meal moth Plodia interpunctella: Comparison of midgut proteinases from susceptible and resistant larvae. J. Invertebr. Pathol. 55, 235-243.

Johnson M. T. and Gould R. (1992) Interaction of genetically engineered host plant resistance and natural enemies of Heliothis virescens (Lepidoptera: Noctuidae) in tobacco. Environ. Entomol. 21, 586597.

Keller M., Sneh B., Strizhov A., Prudovsky N., Regev A., Koncz C., Schell J. and Zilberstein A. (1996) Digestion $\delta$-endotoxin by gutproteases may explain reduced sensitivity of advancedinstars of Spodoptera littoralis to CryIC. Insect Biochem. Molec. Biol. 26, 365-373.

Knowles B. H. and Dow J .A. T. (1993) The crystalendotoxin of Bacillus thuringiensis: Models for their mechanism of action on the insect gut. Bioessays 15, 469.

Koziel M. G., Beland G. L., Bowman C., Carozzi N. B., Crenshaw R., Crossland L., Dawson J., Desai N., Hill M., Kadwell S., Launis K., Lewis K., Maddox D., McPherson K., Meghji M. R., Merlin E., Rhodes R., Warren G. W., Wright M. and Evola S. V. (1993) Field performance of elite transgenic maize plants expressing an insecticidal protein derived from Bacillus thuringiensis. Bio/Technology 11, 194-200.

Lee M. K., Milne R. E., Ge A. Z. and Dean D. H. (1992) Location of Bombyx mori receptor binding on Bacillus thuringiensis delta-endotoxin.J. Biol. Chem. 267, 31153121.

Li J., Carroll J. and Ellar D. J. (1991) Crystal structure of insecticidal $\delta$-endotoxin from Bacillus thuringiensis at $2.5 \AA$ resolution. Nature $353,815-817$.

McGaughey W. H. and Whalon M. E. (1992) Managing insect resistance to Bacillus thuringiensis toxins. Science 258, 1451-1455.

Mihm J. A. (1989) Evaluating maize for resistance to tropical stem borers, armyworm, and earworms, pp. 109-121. In Toward Insect Resistant Maize for the Third World. Proceedings of the International
Symposium on Methodologies for Developing Host Plant Resistance to Maize Insects, 9-14 March 1987, CIMMYT, Mexico. CIMMYT, Mexico, Mexico D.F. Perlak F. J., Fuchs R. L., Dean D. A., McPherson S. L. and Fischoff D. A. (1991) Modification of coding sequence enhances plant expression of insect control protein genes. Proc. Natl. Acad. Sci. USA 88, 33243328.

RaineriD. M., Bottino P., GordonM. P. and Nester E. W. (1990) Agrobacterium-mediated transformation of rice (Oryza sativa L.). Biotechnology 8, 33-38.

Rossiter M., Yendol W. G. and Dubois N. R. (1990) Resistance to Bacillus thuringiensis in gypsy moth (Lepidoptera: Lymantriidae): Genetic and environmental causes. J. Econ. Entomol. 83, 22112218.

Salama H. S. and Sharaby A. (1985) Histopathological changes in Heliothis armigera infected with Bacillus thuringiensis as detected by electron microscopy. Insect Sci. Applic. 6, 503-511.

Schwartz J. L., Garneau L., Savaria D., Masson L., Brousseau R. and Rousseau E. (1993) Lepidopteranspecific crystal toxins from Bacillus thuringiensis form cation and anion-selective channels in planar lipid bilayer. J. Membrane Biol. 132, 53-62.

Serratos J. A., Willcox M. C. and Castillo-Gonzalez F. (Eds) (1997) Gene Flow Among Maize Landraces, Improved Maize Varieties, and Teosinte: Implications for Transgenic Maize. CIMMYT, Mexico, D.F.122pp.

Shelton A. M., Robertson J. L., Tang J. D., Perez C., Eigenbrode S. D., Preisler H. K., Wilsey W. T. and Cooley R. J. (1993) Resistance of diamondbackmoth (Lepidoptera: Plutellidae) to Bacillus thuringiensis subspecies in the field. J. Econ. Entomol. 86, 697-705.

Sneh B. and Schuster S. (1981) Recovery of Bacillus thuringiensis and other bacteria from larvae of Spodoptera littoralis Boisd. previously fed on $B$. thuringiensis-treated leaves. J. Invertebr. Pathol. 37, 295-303.

Starks K. J., Muniappan R. and Eikenbary R. D. (1972) Interaction between plant resistance and parasitism against greenbug on barley and sorghum. Ann. Entomol. Soc. Am. 65, 650-655.

Tabashnik B. (1994) Evolution of resistance to Bacillus thuringiensis. Annu. Rev. Entomol. 39, 47-79.

Tailor R., Tippett J., Gibb G., Pells S., Pike D., Jordan L. and ElyS.(1992) Identification and characterization of a novel Bacillus thuringiensis-endotoxin entomocidal to coleopteran and lepidopteran larvae. Mol. Microbiol. 6, 1211-1217.

USDA (1995) Genetically engineered organisms and products: Simplification of requirements and procedures for genetically engineered organisms. 7 CFR 340. Federal Register 60, 43567-43573.

van Rie J., Jansens S., Höfte H., Degheele D. and van MellaertH. (1989)Specificity of Bacillus thuringiensis $\delta$-endotoxins. Importance of specific receptors on the brush border membrane of the mid-gut of target insects. Eur. J. Biochem. 186, 239-247.

van Rie J., McGaughey W. H., Johnson D. E., Barnett B. 
D. and van Mellaert H. (1990) Mechanism of insect resistance to the microbial insecticide Bacillus thuringiensis. Science 247, 72-74.

Wu D. and Aronson A. I. (1990) Use of mutagenic oligonucleotides for defining regions of a Bacillus thuringiensis $\delta$-endotoxin involved in toxicity, pp. 273-277. In Proc. 5th Int. Colloquim on Invertebrate Pathology and Microbial Control, Adelaide, Australia, 20-24 August 1990. Soc. Invertebrate Pathology, Adelaide, Australia. 